\title{
Çeşitli Kuraklık İndisleri ile Batman İlinin Kuraklık Analizi ve Kontur Haritalarının Çıkarılması
}

\author{
Murat Batan ${ }^{1, \star}(\mathbb{D}$ \\ ${ }^{1}$ Batman Üniversitesi, Mühendislik-Mimarlık Fakültesi, Inşaat Mühendisliği Bölümü, 72100, Batman.

\section{Özet}

Küresel iklim değişikliği ile kuraklık ve taşkın gibi doğal afetlerde artış gözlenmiştir. Bu nedenle literatürde kuraklık, taşkın gibi doğal afetler üzerine birçok çalışma mevcuttur. Bu çalışmada genel olarak iklim yönünden kurak bir bölge olan Türkiye'nin Güneydoğu Anadolu Bölgesi'nde yer alan Batman ilinde çeşitli kuraklık indisleri ile kuraklık analizi yapılmıştır. Sadece yağlş verilerini dikkate alan Normalin Yüzdesi İndisi (NYI)), Modifiye Fournier İndisi (MFİ) ve Standartlaştırılmış Yağış İndisi (SYİ) ile; yağıs ve sicaklık verilerini birlikte dikkate alan De Martonne-Gotmann İndisi (DMGI) ve Bagnauls-Gaussen Indisine (BGI) göre analizler yapılmıştır. Bu analizlerde Batman iline ait 1988-2018 yilları arası Meteoroloji Bölge Müdürlüğ̈̈nden temin edilen 31 yıllık sicaklık ve yağıs verileri kullanılmıștır. Analiz sonuçlarına göre, beș yöntemin sonuçlarının birebir uyușmadığı görülmüștür. NYİ indisine göre; 23 yılın normal, 1 yılın hafif kurak, 5 yllın orta kurak ve 2 yılın şiddetli kurak olduğu, MFI indisine göre; 4 yılın çok az yağışll, 18 yılın az

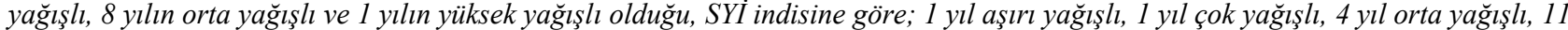
yıl hafif yağışlı, 8 yll hafif kurak, 3 yıl orta kurak, 3 yl çok kurak olduğu, DMGİ indisine göre; 10 yılın yarı kurak-nemli arasl, 21 yılın yarı kurak olduğu ve BGI indisine göre ise tüm yılların çok kurak olduğu tespit edilmiştir. Makalede Standartlaştırılmış Yağış Indisi (SYI) ile yıllık analizlerin yanında mevsimlik analizler de yapılmıştır. Bazı yöntemlerin analiz sonuçlarının SURFER haritalama programıyla kontur haritaları da çıkarılıp görselleştirilmiştir.

Anahtar Sözcükler

Batman, Normalin Yüzdesi İndisi, Modifiye Fournier İndisi, Standartlaştırılmış Yağış İndisi, De Martonne-Gotmann İndisi, BagnaulsGaussen İndisi

\section{Drought Analysis of Batman Province with Various Drought Indices and Contour Maps}

\begin{abstract}
Natural disasters such as drought and flood along with global climate change, have increased in recent years. Therefore, there are many studies on drought and flood in the literature. In this study, they have been made drought analysis with various drought indices in Batman province located Southeastern Anatolia Region of Turkey which is generally an arid region in terms of climate. They were made analyses for Batman province with Percent of Normal Index (PNI), Modified Fournier Index (MFI) and Standardized Precipitation Index (SPI) that only takes into account the rainfall data and with De Martonne-Gotmann Index (DMGI) and BagnaulsGaussen Index (BGI), which take into account the rainfall and the temperature data together. 31-years of temperature and precipitation data between 1988 and 2018 belong to Batman province obtained from the Meteorology Regional Directorate were used in these analyses According to the analysis results, it was seen that the results of the five methods did not match exactly. According to the PNI; 23 years are normal, 1 year mildly arid, 5 years moderately arid and 2 years severely dry. According to the MFI; 4 years are very little rain, 18 years' little rain, 8 years' moderate precipitation and 1-year high rainfall. According to the SPI; 1 year was excessive rainfall, 1-year heavy rainfall, 4 years' moderate precipitation, 11 years lightly rainy, 8 years mildly arid, 3 years moderately arid and 3 years very dry. According to the DMGI; 10 years are between semi-arid-humid, 21 years semi-arid. According to the BGI has been determined that all years are very dry. In the article, in addition to the annual analyses with the Standardized Precipitation Index seasonal analyses were also made. Contour maps of the analysis results for some methods were also visualized with the SURFER mapping program.
\end{abstract}

\section{Keywords}

Batman, Percent of Normal Index, Modified Fournier Index, Standardized Precipitation Index, De Martonne-Gotmann Index, Bagnauls-Gaussen Index. 


\section{Giriş}

Kuraklık toplumu, ekonomiyi, tarımsal faaliyetleri ve sosyal hayatı etkileyen şiddetli su eksikliğine dayanan iklimsel bir olaydır (Şen 1998; Hisdal ve Tallaksen 2003; Mishra ve Singh 2010). Bazı araştırmacılar da kuraklığı, su eksikliğinin bir dönem sürmesi olarak tanımlamışlardır (Kao ve Govindaraju 2010). Kuraklık tekerrür eden su eksikliği olarak tanımlansa da, kuraklığı, bir dönem içinde meydana gelen su eksikliği olarak düşünmemek gerekir. Kuraklığı, kuraklık çeşitleri olarak da bilinen, hidrolojik kuraklık, meteorolojik kuraklık, sosyo-ekonomik kuraklık ve tarımsal kuraklık olarak dört sınıfta geniş kapsamda etkileri olan ve bu etkilerin su eksikliği ile şiddetlendiği uzun dönemli olaylar olarak tanımlamak gerekir (Mishra ve Singh 2010; Choi vd. 2013; Dabanlı 2017). Literatür incelendiğinde, kuraklığın; şiddetiyle, süresiyle, alansal ve zamansal etkileriyle, kısacası tüm boyutları ile incelendiği anlaşılmaktadır (Şen 1978; Dai 2011; Xu vd. 2015).

Belirli dönemlerde, belirli periyotlarla meydana gelen su eksikliği nedeniyle kuraklık tarımsal faaliyetleri büyük ölçüde etkilemekte ve bunun sonucunda toplumun tümden sosyo-ekonomik durumu etkilenmektedir (Hınıs 2013). Yapılan bir çalışmaya göre; 31 çeşit doğal afet içinde kuraklık birinci sırada bulunmaktadır (Bryant 1993). Etki alanı ve olumsuz etkileri bu kadar büyük olan bir olayın önceden belirlenmesi maddi kayıplar ve can kayıpları açısından oldukça önemlidir. Dünyanın her tarafında birçok araştırmacı kuraklığın hangi bölgelerde etkili olduğu, hangi zaman aralıklarıyla tekerrür ettiği, ileriye dönük kuraklık tahminleri gibi çalışmalar yaparak ve yetkili kişilerce bu çalışma sonuçları doğrultusunda tedbirler alınarak kuraklığın insanoğlu üzerindeki olumsuz etkileri azaltılmaya çalışılmaktadır (Efe ve Özgür 2014; Hamidi 2018; Gümüş vd. 2016; Yılmaz 2017; Tadic vd. 2015). Bazı çalışmalarda iklim değişikliğine uyum da bir çözüm olarak düşünülmektedir (Batan ve Toprak 2015).

Literatürde kuraklık üzerine bölgesel (Faiz vd. 2020; Yenigun ve Ibrahim 2019; Partal ve Yavuz 2020) ya da havza bazlı çalışmaların (Dikici 2019; Dikici ve Aksel 2019; Jain vd. 2020; Arslan vd. 2016) yanında il bazında (Dabanlı 2017; Salehnia vd. 2017; Doğan vd. 2012; Taş ve Kilit 2015; Hamidi vd. 2013a) çalışmalar da yapılmıştır.

Kuraklık analizi için birçok yöntem kullanılmaktadır. Bu yöntemlerden bazıları; Standartlaştırılmış Yağış İndisi(SYİ), Normalin Yüzdesi İndisi(NYİ), De Martonne-Gotmann İndisi(DMGI), Thornthwaite Yöntemi İndisi(TYI), Modifiye Fournier İndisi(MFİ), Erinç Kuraklık İndisi(EKİ), Bagnauls-Gaussen İndisi(BGI) ve diğerleridir (Hamidi vd. 2013b; Hamidi 2018). Bir bölgenin kuraklık ve nemlilik durumlarını belirleyen bu analiz yöntemlerinden bazıları, çalışma alanına ait sadece yağış verilerini kullanmakta, bazıları da hem yağış hem sıcaklık verilerini kullanmaktadır. Mesela; SYİ, NYİ ve MFİ indisleri sadece yağış verilerini kullanmakta, DMGİ ve BGİ indisleri ise hem yağış hem de sıcaklık verilerini kullanmaktadir.

Kuraklığın asıl tetikleyicilerinden olduğu kabul edilen küresel ısınma, dünyanın pek çok bölgesinde iklim değişkenleri üzerindeki olumsuz etkisi nedeniyle kuraklığın yayılmasına neden olmaktadır. Ayrıca, iklim değişikliğinin birçok bölge üzerinde kuraklığın görülme sıklığını da arttırdığı iddia edilmektedir (Blenkinsop ve Fowler 2007; Guardiola-Claramonte vd. 2011; Batan 2014).

Bu çalışmada; Batman ili için, Meteoroloji Bölge Müdürlüğünden temin edilen uzun yıllar (1988-2018) yağış ve sıcaklık verileri kullanılarak, Batman İli için kuraklık analizleri yapılmıştır. Batman ilinin seçilmesinin nedeni daha önce anılan yöntemler ile bu il için bir kuraklık analizinin yapılmamış olmasıdır. Kuraklık hakkında bir fikir elde etmek için yağı̧̧ verileri kullanılarak NYİ ve MFİ kuraklık indislerine göre ve yağış ve sıcaklık verileri kullanılarak DMGİ ve BGİ indislerine göre analizler yapılmıştır. Daha sonra literatürde en fazla kullanılan Standartlaştırılmış Yağış İndisi (SYI) yöntemi ile de yıllık ve mevsimlik analizler yapılıp, diğer yöntemler ile ve literatür sonuçları ile karşılaştırılmıştır. Analiz sonuçları dairesel grafiklerle görselleştirilip kıyaslanmıştır. Ayrıca kullanılan MFİ ve BGİ kuraklık indisleri sonuçlarının SURFER haritalama programıyla kontur haritaları çıkarılmış ve sonuçlar karşılaşıııılmıştır.

\section{Materyal ve Yöntem}

\section{1.Çalışma Alanı ve Veriler}

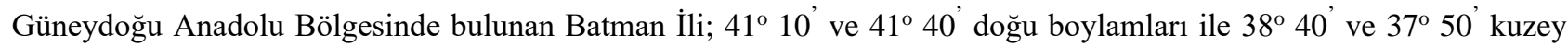
enlemleri arasında bulunmaktadır. Kuzeyi, kuzeydoğusu ve güneyi dağlık ve engebeli bir yapıya sahiptir. Batıdan doğuya akan Dicle nehrine Batman şehir merkezinden geçen ve Dicle nehrinin en önemli kollarından biri olan Batman çayı katılmaktadır. 550 metre rakıma sahip olan Batman'da karasal iklim görülmektedir. İlde yazlar sıcak ve kurak, kışlar yağışlı ve soğuk geçer. İl sınırları içinde sulama amaçlı yapılan Gercüş-Kırkat göleti ile elektrik üretim amaçlı yapılan Kozluk-Ceffan göleti bulunmaktadır (URL-1 2020). 


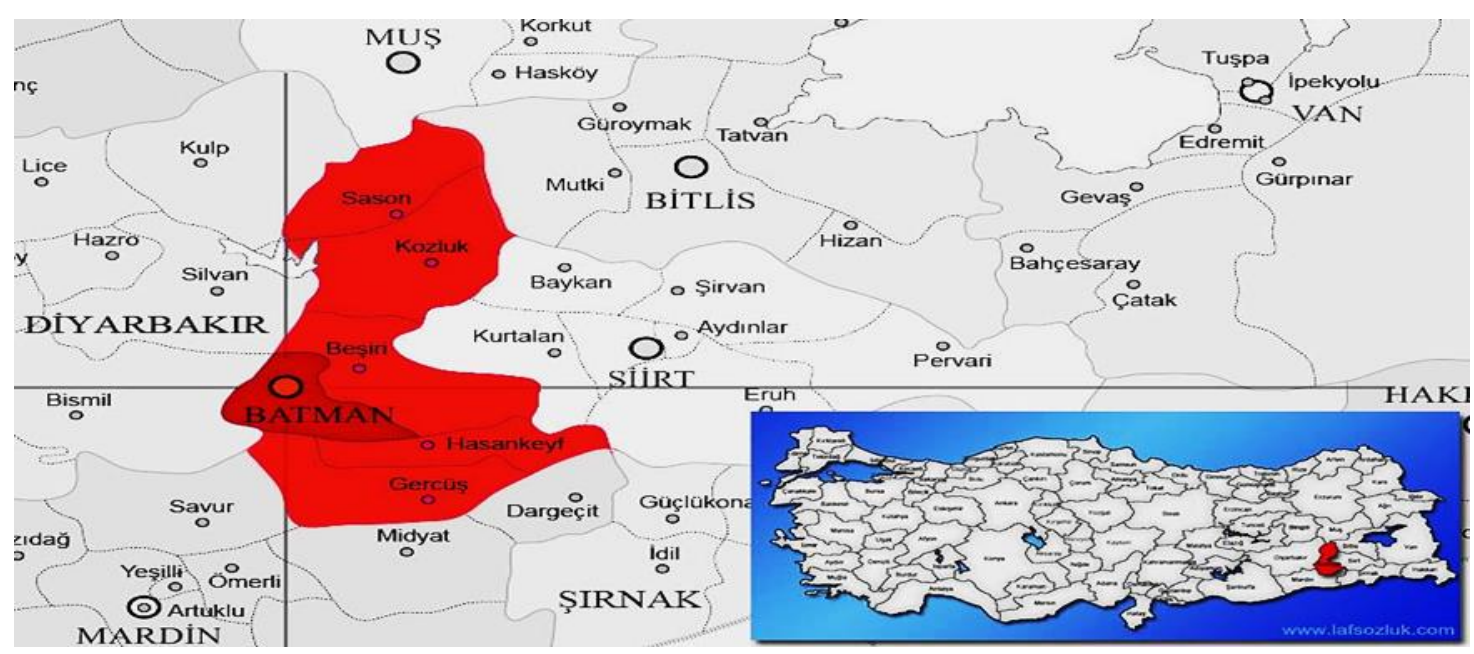

Şekil 1: Batman ilinin konumu ve idari sınırları (URL-2 2020)

Bu çalışmada, yağış verilerini kullanan Normalin Yüzdesi İndisi yöntemi için; Meteoroloji Bölge Müdürlüğünden temin edilen 1988-2018 arası yıllara ait, Batman ilinin 31 yıllık ortalama aylık yağış miktarları ve 31 yıllık ortalama yıllık yağış miktarları kullanılmıştır. Yine yağış verilerini kullanan Modifiye Fournier İndisi yöntemi için ise çalışma periyodu olan 1988-2018 yılları için aylık toplam yağışlar ve yıllık yağış ortalamaları kullanılmıştır. Literatürde en fazla kullanılan ve yine yağış verilerini kullanan Standartlaştırılmış Yağış İndisi yöntemi (SYİ) için de; mevsimlik dönemler halinde oluşturulmuş 31 yıllık aylık yağışlar ve uzun dönemli (31 yıllık) yıllık yağış ortalamaları kullanılmıştır.

Sıcaklık ve yağış verilerini birlikte dikkate alan De Martonne-Gotmann İndisi yöntemi için ise; 1988 -2018 yılları arasına ait, Batman ilinin 31 yıllık toplam yağış miktarları, 31 yıllık ortalama sıcaklık değerleri, 31 yıldaki en kurak ayların yağış ve sıcaklık değerleri kullanılmıştır. Ortalama değerler aritmetik ortalama kullanılarak bulunmuştur (Hamidi, 2018). Sicaklık ve yağış verilerini kullanan diğer yöntem olan, Bagnauls-Gaussen İndisi yönteminde ise aylık ortalama sıcaklık ve aylık toplam yağış değerleri kullanılmıştır.

\subsection{Kuraklık İndisleri}

\subsubsection{Normalin Yüzdesi İndisi (NYí) Yöntemi}

NYİ kuraklık indisleri arasında yaygın olarak kullanılan ve yağış verilerini esas alan bir yöntemdir. Belirli bir zaman dilimi içindeki yağış miktarının aynı zaman dilimindeki yağış miktarının ortalamasına bölünerek NY değeri bulunan ve 100 çarpanıyla da çarpılıp yüzdeliğe çevrilmiş NY değeri bulunabilen bir yöntemdir (URL-3 2020)

$\mathrm{NYI}=\left(\frac{\mathrm{Pi}}{\mathrm{Pi}(\mathrm{ort})}\right) \times 100$

Denklemde NYI Normalin Yüzdesi İndis değerini, Pi( $\mathrm{mm})$ aktüel yağış miktarını, Pi(ort)(mm) ise ortalama yağıŞ miktarını ifade etmektedir. Aşağıda NYİ sınıflandırma tablosu verilmiştir. Bu çalışmada Tablo 1'de verilen 12 aylık periyot için sınıflandırma yapılmıştır. NYİ değerlerine göre 5 ayrı periyot için 4 ayrı kuraklık sınıfı oluşturulmuştur.

\subsubsection{Modifiye Fournier İndisi (MFi) Yöntemi}

$\mathrm{Bu}$ yöntemde de NYİ yönteminde olduğu gibi sadece yağış verileri kullanılır. MFİ indis değerinin hesaplanmasında kullanılan eşitlik aşağıda verilmiştir.

$\mathrm{MFI}=\sum_{i=1}^{12}\left(\frac{\mathrm{Pi}^{2}}{\mathrm{P}}\right)$

Burada, $P i(\mathrm{~mm})$ i ayında toplam yağışı, $P(\mathrm{~mm})$ yıllık ortalama yağış miktarını ifade etmektedir. Tablo 1 'de MFİ sınıflandırma tablosu verilmiştir. Tabloya göre MFİ değerlerine göre 5 ayrı sınıf oluşturulmuştur. 
Tablo1: Normalin yüzdesi indisi ve modifiye fournier indisi sınıflandırma tablosu (Şimşek ve Çakmak 2020)

\begin{tabular}{|c|c|c|c|c|}
\hline \multicolumn{5}{|c|}{ NORMALIN YÜZDESI İNDİİ } \\
\hline Periyot & Normal & Hafif Kurak & Orta Kurak & $\begin{array}{c}\text { Şiddetli } \\
\text { Kurak }\end{array}$ \\
\hline 1 & $>\% 75$ & $\% 65-\% 75$ & $\% 55-\% 65$ & $<\% 55$ \\
\hline 3 & $>\% 75$ & $\% 65-\% 75$ & $\% 55-\% 65$ & $<\% 55$ \\
\hline 6 & $>\% 80$ & $\% 70-\% 80$ & $\% 60-\% 70$ & $<\% 60$ \\
\hline 9 & $>\% 83,5$ & $\% 83,5$ & $\% 63,5-$ & $<\% 63,5$ \\
\hline 12 & $>\% 85$ & $\% 75-\% 85$ & $\% 65-\% 75$ & $<\% 65$ \\
\hline
\end{tabular}

\begin{tabular}{|c|c|}
\hline \multicolumn{2}{|c|}{$\begin{array}{c}\text { MODIFIYE FOURNIER } \\
\text { INDISI }\end{array}$} \\
\hline$<60$ & Çok az \\
\hline $60-90$ arası & Az \\
\hline 91- 120 arası & Orta \\
\hline $121-160$ arası & Yüksek \\
\hline$>160$ & Çok Yüksek \\
\hline
\end{tabular}

\subsubsection{Standartlaştırıımış Yağış İndisi (SYi) Yöntemi}

Kuraklığın belirlenmesinde yaygın olarak kullanılan SYİ yöntemi, yağış toplamlarına gamma olasılık yoğunluk fonksiyonunu uydurmayı içerir. Denklem 3'te görüldüğü gibi aylık yağışlar ve uzun dönemli yağış ortalamaları arasındaki farkın standart sapmaya bölünmesi ile normalize edilerek elde edilmektedir (Gümüş vd. 2016).

$$
\mathrm{SYİ}=\left(\frac{\mathrm{Xij}-\mathrm{Xim}}{\sigma}\right)
$$

Burada $X_{i j}$ i. yağış istasyonundaki j. gözlemdeki aylık yağışı, $X_{i m}$ uzun dönemli yağış ortalamasını ve $\sigma$ standart sapmayı ifade etmektedir.

Tablo 2: Standartlaştırılmış Yağış Indisi sınıflandırma tablosu (Gümüş vd. 2016; Edossa vd. 2010)

\begin{tabular}{|c|c|}
\hline \multicolumn{2}{|c|}{ STANDARTLAŞTIRILMIŞ YAĞIŞ İNDİSI } \\
\hline SYI $>2.0$ & Aşırı Yağışlı \\
\hline $1.5<$ SYI $\leq 2.0$ & Çok Yağışı ı \\
\hline $1.0<$ SYI $\leq 1.5$ & Orta Yağışlı \\
\hline $0<$ SYI $\leq 1.0$ & Hafif Yağışlı \\
\hline$-1<$ SYI $\leq 0$ & Hafif Kurak \\
\hline$-1.5<$ SYI $\leq-1.0$ & Orta Kurak \\
\hline$-2.0<$ SYI $\leq-1.5$ & Çok Kurak \\
\hline SYI $\leq-2$ & Aşırı Kurak \\
\hline
\end{tabular}

\subsubsection{De Martonne-Gotmann İndisi (DMGi) Yöntemi}

$\mathrm{Bu}$ yöntem ile bir bölgenin iklim tipi belirlenirken öncelikle belirlenen zaman dilimi içindeki toplam yağış ve ortalama sıcaklık verileri kullanılır. Bu verilerin yanına en kurak ayın yağış ve sıcaklık değerleri alınmıştır. Bu değer en düşük indis değeri olan ayın değeridir. Bu veriler kullanılarak aşağıda verilen denklem sayesinde kuraklık şiddetini belirleyen indis değerleri bulunur. Formüldeki 10 değeri, sıcaklığın sıfırın altında olduğu zamanlarda sıcaklık değerini pozitif yapmaya yarayan bir sabittir (URL-3 2020; Aktaş vd. 2018). De Martonne-Gotmann İndisi yöntemi sıcaklık ve yağış verilerini dikkate alan ve temeli buharlaşmanın iklim ve kuraklık üzerine etkisine dayanan bir yöntemdir (Aktaş vd. 2018). 
$\mathrm{DMGI}=\frac{1}{2} *\left(\frac{\mathrm{P}}{\mathrm{T}+10}+\frac{12 * \mathrm{Pd}}{\mathrm{Td}+10}\right)$

Denklemde DMGI De Martonne-Gotmann indis değerini, $P(m m)$ yıllık toplam yağ ${ }_{1 S ̧}$ miktarını, $T\left({ }^{0} C\right)$ yıllık ortalama sıcaklık değeri, $P_{d}(\mathrm{~mm})$ en kurak ay yağış miktarı, $T_{d}\left({ }^{0} \mathrm{C}\right)$ ise en kurak ay sıcaklık değerini ifade etmektedir. De Martonne Gotmann kuraklık indisi sınıflandırma tablosu aşağıda Tablo 3’te verilmiştir. Tabloda DMGI indis değerlerine göre 6 ayrı kuraklık sınıfı oluşturulmuştur.

\subsubsection{Bagnauls-Gaussen İndisi (BGi) Yöntemi}

$\mathrm{Bu}$ yöntemde de bölgenin kuraklık analizi yapılırken aylık ortalama sıcaklık ve aylık toplam yağış miktarları aşağıdaki formülde kullanılarak BGİ kuraklık indisi değeri belirlenir. Kuraklık indisi BGİ için ki değerleri, sadece aylık ortalama sıcaklığın iki katının, aynı ayda kaydedilen toplam yağış miktarından daha fazla olduğu aylarda hesaplanmaktadır (Akar vd. 2015; Hamidi 2018)

$\mathrm{BGI}=\sum_{i=1}^{12}(2 \mathrm{ti}-\mathrm{Pi}) \mathrm{ki}, \mathrm{ki}=(2 \mathrm{ti}-\mathrm{Pi})>0$

Yukarıdaki denklemde $k i$ sıfırdan büyük olduğu ayın $(k i>0)$ değerlendirmesini gösterir. $t i\left({ }^{0} C\right)$, i ayındaki aylık ortalama sıcaklığı, Pi( $\mathrm{mm}$ ) ise i ayındaki aylık toplam yağış miktarını ifade etmektedir. Bagnauls-Gaussen İndisi (BGI) tablosu aşağıda Tablo 3 'te verilmiştir. Tabloda BGİ indis değerlerine göre 4 ayrı kuraklık sınıfı oluşturulmuştur.

Tablo 3: De Martonne Gotmann ve Bagnauls-Gaussen indisleri için sınıflandırma tabloları (URL-3 2020; Akar vd. 2015)

\begin{tabular}{|c|c|}
\hline \multicolumn{2}{|c|}{ DE MARTONNE GOTMANN İNDÍSI } \\
\hline DMGİ & Tanımı \\
\hline 5'ten küçük & Kurak \\
\hline 5- 10 arası & Yarı Kurak \\
\hline 10- 20 arası & Yarı Kurak-Nemli arası \\
\hline 20- 30 arası & Yarı Nemli \\
\hline 30-60 arası & Nemli \\
\hline$>60$ & Çok Nemli \\
\hline
\end{tabular}

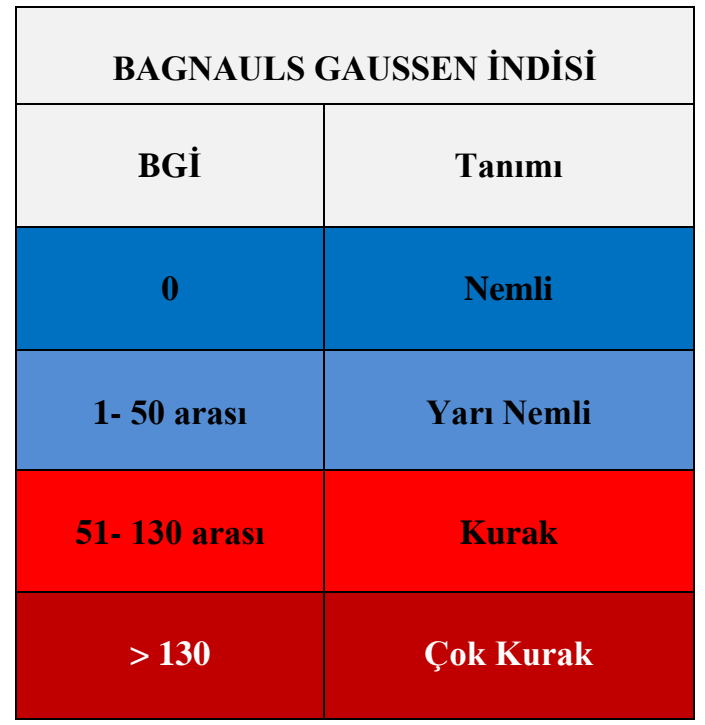

\section{Bulgular ve Tartışma}

\subsection{Batman İli Uzun Yıllar Kuraklık Analiz Sonuçları}

Aşağıda Tablo 4'te Batman iline ait 1988-2018 yılları arası 31 yıllık kuraklık analiz sonuçları verilmiştir. Analizler 4 ayrı yöntemle yapılmıştır. Bu analiz sonuçları incelendiğinde; NYİ yöntemine göre 23 yılın normal, 1 yılın hafif kurak, 5 yılın orta kurak ve 2 yılın şiddetli kurak olduğu, MFİ yöntemine göre; 4 yılın çok az yağışlı, 18 yılın az yağışlı, 8 yılın orta yağışılı ve 1 yılın yüksek yağışı olduğu, DMGİ yöntemine göre; 10 yılın yarı kurak-nemli arası, 21 yılın yarı kurak olduğu ve BGİ yöntemine göre ise tüm yılların çok kurak olduğu tespit edilmiştir. Bu sonuçlar Şekil 2.'de karşılaştırılmıştır. 


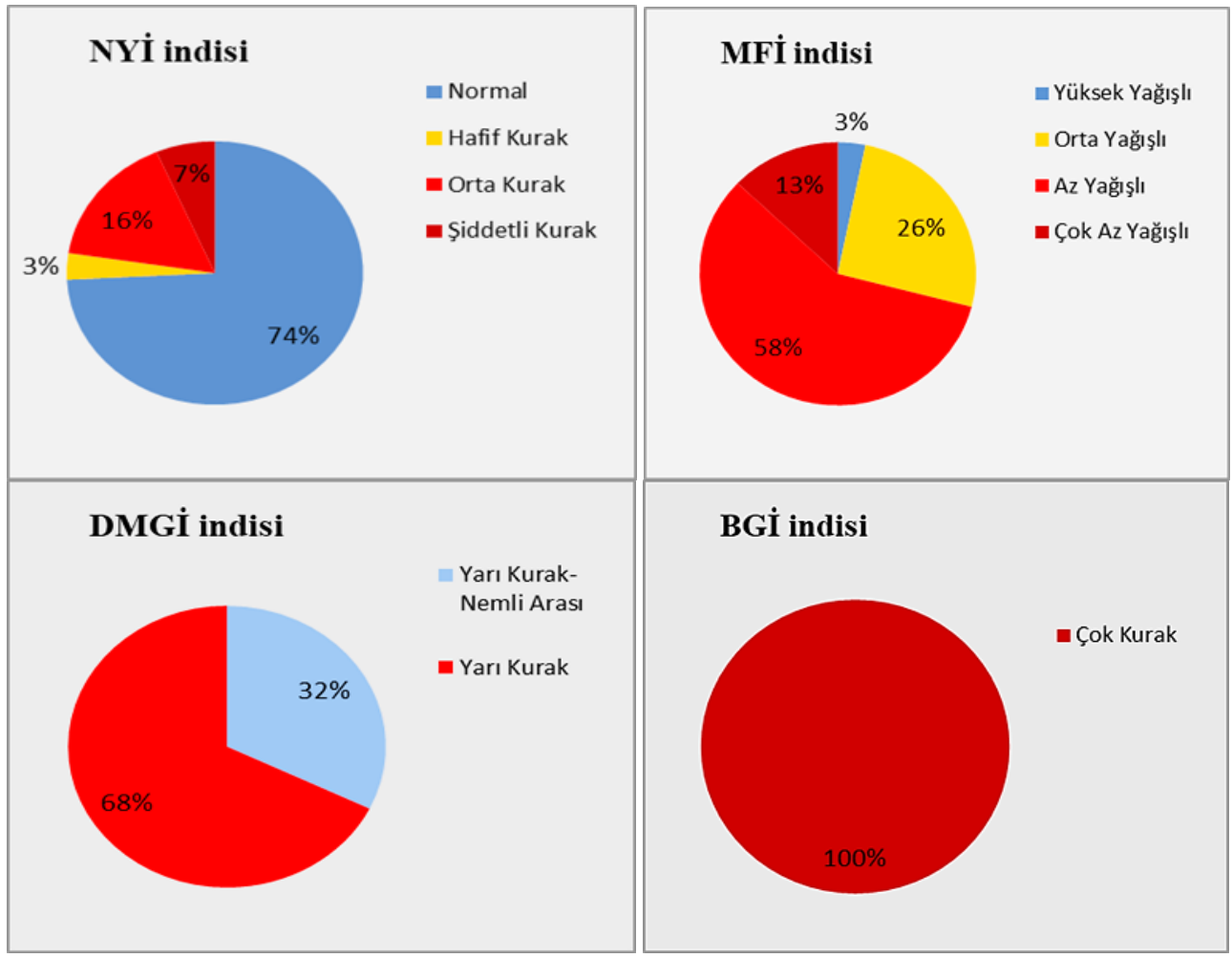

Şekil 2: Çeşitli indislere göre Batman ili uzun yıllar kuraklık analizi sonuçlarının grafiksel gösterimi

Şekil 2'deki dairesel grafiklerde görüldüğü üzere NYİ'de normal yıllar fazla, BGİ'de yılların tamamı kuraktır. MFİ ve DMGI yöntemlerine göre kurak yıllar fazla olup, iki yöntem sonuçları itibariyle birbirine daha uyumlu yöntemlerdir. Analizde kullanılan 4 yöntemden 3'ünde kurak yıllar fazla çıkmıştır. Batman gibi sıcaklık ortalamalarının ve özellikle yaz aylarında buharlaşmanın fazla olduğu bir bölgede böyle bir eğilimin olmasının normal olduğu ve olması gerekenin de bu olduğu düşünülmektedir. Analizlerde kullanılan 4 yönteme ait sonuçlar Tablo 4'te ayrıntılı olarak verilmiştir.

Tablo 4: Batman ili 1988-2018 yılları arası dönem için çeşitli indislere göre kuraklık analizi sonuçları

\begin{tabular}{|c|c|c|c|c|c|c|c|c|}
\hline & \multicolumn{2}{|c|}{$\begin{array}{l}\text { NORMALİN } \\
\text { YÜZDESİ }\end{array}$} & \multicolumn{2}{|c|}{$\begin{array}{l}\text { MODIFIYYE } \\
\text { FOURNIER } \\
\end{array}$} & \multicolumn{2}{|c|}{$\begin{array}{c}\text { DE MARTONNE } \\
\text { GOTMANN }\end{array}$} & \multicolumn{2}{|c|}{$\begin{array}{c}\text { BAGNAULS } \\
\text { GAUSSEN }\end{array}$} \\
\hline YILLAR & $\begin{array}{c}\text { INDİS } \\
\text { DEĞERİ }\end{array}$ & SINIFI & $\begin{array}{l}\text { İNDİS } \\
\text { DEĞERİ }\end{array}$ & SINIFI & $\begin{array}{c}\text { INDİS } \\
\text { DEĞERİ }\end{array}$ & SINIFI & $\begin{array}{c}\text { İNDİS } \\
\text { DEĞERİ }\end{array}$ & SINIFI \\
\hline 1988 & 156,25 & Normal & 101,35 & Orta & 14,14 & $\begin{array}{c}\text { Yarı Kurak-Nemli } \\
\text { Aras1 }\end{array}$ & 204,6 & $\begin{array}{l}\text { Çok } \\
\text { Kurak }\end{array}$ \\
\hline 1989 & 72,65 & Orta Kurak & 73,69 & $\mathrm{Az}$ & 6,29 & Yar1 Kurak & 280,7 & $\begin{array}{l}\text { Çok } \\
\text { Kurak }\end{array}$ \\
\hline 1990 & 74,82 & Orta Kurak & 61,72 & $\mathrm{Az}$ & 6,51 & Yarı Kurak & 290,4 & $\begin{array}{l}\text { Çok } \\
\text { Kurak }\end{array}$ \\
\hline 1991 & 116,91 & Normal & 92,40 & Orta & 10,29 & $\begin{array}{c}\text { Yarı Kurak-Nemli } \\
\text { Aras1 }\end{array}$ & 166,1 & $\begin{array}{c}\text { Çok } \\
\text { Kurak }\end{array}$ \\
\hline 1992 & 107,56 & Normal & 73,84 & $\mathrm{Az}$ & 10,1 & $\begin{array}{c}\text { Yarı Kurak-Nemli } \\
\text { Aras1 }\end{array}$ & 210,8 & $\begin{array}{c}\text { Çok } \\
\text { Kurak }\end{array}$ \\
\hline
\end{tabular}


Tablo 4'ün devamı

\begin{tabular}{|c|c|c|c|c|c|c|c|c|}
\hline 1993 & 123,15 & Normal & 113,53 & Orta & 11,2 & $\begin{array}{c}\text { Yar1 Kurak-Nemli } \\
\text { Aras1 }\end{array}$ & 240,9 & $\begin{array}{l}\text { Çok } \\
\text { Kurak }\end{array}$ \\
\hline 1994 & 128,6 & Normal & 67,68 & $\mathrm{Az}$ & 10,85 & $\begin{array}{c}\text { Yarı Kurak-Nemli } \\
\text { Arası }\end{array}$ & 226,2 & $\begin{array}{l}\text { Çok } \\
\text { Kurak }\end{array}$ \\
\hline 1995 & 95,09 & Normal & 82,08 & $\mathrm{Az}$ & 8,24 & Yarı Kurak & 259,7 & $\begin{array}{l}\text { Çok } \\
\text { Kurak }\end{array}$ \\
\hline 1996 & 141,07 & Normal & 153,52 & Yüksek & 12,11 & $\begin{array}{c}\text { Yar1 Kurak-Nemli } \\
\text { Aras1 }\end{array}$ & 274,5 & $\begin{array}{l}\text { Çok } \\
\text { Kurak }\end{array}$ \\
\hline 1997 & 98,2 & Normal & 52,65 & Çok az & 8,78 & Yarı Kurak & 193,6 & $\begin{array}{l}\text { Çok } \\
\text { Kurak }\end{array}$ \\
\hline 1998 & 84,18 & Hafif Kurak & 63,33 & $\mathrm{Az}$ & 7,07 & Yarı Kurak & 279,8 & $\begin{array}{l}\text { Çok } \\
\text { Kurak }\end{array}$ \\
\hline 1999 & 70,15 & Orta Kurak & 69,05 & $\mathrm{Az}$ & 5,9 & Yarı Kurak & 309,7 & $\begin{array}{l}\text { Çok } \\
\text { Kurak }\end{array}$ \\
\hline 2000 & 85,73 & Normal & 65,73 & $\mathrm{Az}$ & 6,88 & Yarı Kurak & 291,4 & $\begin{array}{l}\text { Çok } \\
\text { Kurak }\end{array}$ \\
\hline 2001 & 97,43 & Normal & 77,45 & $\mathrm{Az}$ & 8,33 & Yarı Kurak & 233,6 & $\begin{array}{l}\text { Çok } \\
\text { Kurak }\end{array}$ \\
\hline 2002 & 102,88 & Normal & 92,06 & Orta & 8,98 & Yarı Kurak & 270,1 & $\begin{array}{l}\text { Çok } \\
\text { Kurak }\end{array}$ \\
\hline 2003 & 112,24 & Normal & 99,23 & Orta & 9,45 & Yarı Kurak & 267,6 & $\begin{array}{l}\text { Çok } \\
\text { Kurak }\end{array}$ \\
\hline 2004 & 66,25 & Orta Kurak & 107,86 & Orta & 5,92 & Yar1 Kurak & 298,2 & $\begin{array}{l}\text { Çok } \\
\text { Kurak }\end{array}$ \\
\hline 2005 & 85,74 & Normal & 68,02 & $\mathrm{Az}$ & 7,69 & Yar1 Kurak & 264,2 & $\begin{array}{l}\text { Çok } \\
\text { Kurak }\end{array}$ \\
\hline 2006 & 133,28 & Normal & 91,75 & Orta & 11,89 & $\begin{array}{c}\text { Yarı Kurak-Nemli } \\
\text { Arası }\end{array}$ & 233,4 & $\begin{array}{l}\text { Çok } \\
\text { Kurak }\end{array}$ \\
\hline 2007 & 74,04 & Orta Kurak & 68,64 & $\mathrm{Az}$ & 7,45 & Yarı Kurak & 270 & $\begin{array}{l}\text { Çok } \\
\text { Kurak }\end{array}$ \\
\hline 2008 & 63,91 & $\begin{array}{l}\text { Şiddetli } \\
\text { Kurak }\end{array}$ & 32,06 & Çok az & 5,63 & Yarı Kurak & 212,9 & $\begin{array}{l}\text { Çok } \\
\text { Kurak }\end{array}$ \\
\hline 2009 & 87,29 & Normal & 64,50 & $\mathrm{Az}$ & 7,89 & Yarı Kurak & 235,4 & $\begin{array}{l}\text { Çok } \\
\text { Kurak }\end{array}$ \\
\hline 2010 & 63,91 & $\begin{array}{l}\text { Şiddetli } \\
\text { Kurak }\end{array}$ & 48,87 & Çok az & 5,42 & Yarı Kurak & 257,7 & $\begin{array}{l}\text { Çok } \\
\text { Kurak }\end{array}$ \\
\hline 2011 & 114,57 & Normal & 108,18 & Orta & 10,48 & $\begin{array}{c}\text { Yarı Kurak-Nemli } \\
\text { Arası }\end{array}$ & 208,7 & $\begin{array}{l}\text { Çok } \\
\text { Kurak }\end{array}$ \\
\hline 2012 & 134,84 & Normal & 88,84 & $\mathrm{Az}$ & 11,76 & $\begin{array}{c}\text { Yarı Kurak-Nemli } \\
\text { Aras1 }\end{array}$ & 224,7 & $\begin{array}{l}\text { Çok } \\
\text { Kurak }\end{array}$ \\
\hline 2013 & 105,22 & Normal & 70,59 & $\mathrm{Az}$ & 9,46 & Yarı Kurak & 243,1 & $\begin{array}{l}\text { Çok } \\
\text { Kurak }\end{array}$ \\
\hline
\end{tabular}


Tablo 4'ün devamı

\begin{tabular}{|c|c|c|c|c|c|c|c|c|}
\hline 2014 & 96,65 & Normal & 53,42 & Çok az & 8,63 & Yar1 Kurak & 195,4 & $\begin{array}{c}\text { Çok } \\
\text { Kurak }\end{array}$ \\
\hline 2015 & 91,97 & Normal & 67,20 & $\mathrm{Az}$ & 8,06 & Yarı Kurak & 243,2 & $\begin{array}{c}\text { Çok } \\
\text { Kurak }\end{array}$ \\
\hline 2016 & 98,2 & Normal & 73,06 & $\mathrm{Az}$ & 8,71 & Yar1 Kurak & 237,5 & $\begin{array}{c}\text { Çok } \\
\text { Kurak }\end{array}$ \\
\hline 2017 & 88,85 & Normal & 78,51 & $\mathrm{Az}$ & 8,06 & Yar1 Kurak & 252,2 & $\begin{array}{c}\text { Çok } \\
\text { Kurak }\end{array}$ \\
\hline 2018 & 127,82 & Normal & 81,84 & $\mathrm{Az}$ & 10,86 & $\begin{array}{c}\text { Yar1 Kurak-Nemli } \\
\text { Aras }\end{array}$ & 218,8 & $\begin{array}{c}\text { Çok } \\
\text { Kurak }\end{array}$ \\
\hline
\end{tabular}

\section{2. Çalışma Sonuçlarının SYi Sonuçları ve Literatürle Karşılaştırılması}

\subsubsection{SYi Yıllık ve SYi Mevsimlik Analiz Sonuçları}

Çalışma bölgesi için DrinC (Drought Indeces Calculator) programı (Tigkas vd. 2015) ile SYİ yıllık (12 aylık) ve mevsimlik (3 aylık) analizler yapılmış ve diğer yöntemlerin sonuçları ile karşılaştırılmıştır. Programda yıllık analiz için log normal dağılım, aylık analiz için gamma dağılımı uygulanmıştır. Kuraklık analizinde SYİ yönteminin çok kullanılan güvenilir bir yöntem olması nedeniyle bu yöntem doğrulama için kullanılmıştır. Çalışma bölgesinde yaz aylarında sıcaklığın çok yüksek olması nedeniyle kuraklık yüksek çıkabileceği gibi, bahar ve kış aylarındaki kuraklığın su kullanımı ve su biriktirme açısından daha önemli olması nedenleriyle mevsimlik değişimleri görebilmek için yıllık (12 aylık) analizlerin yanında mevsimlik (3 aylık) analizler de yapılmıştır. Ayrıca, SYİ yönteminin 3 aylık dönemi kapsayan analiz sonuçları meteorolojik kuraklık açısından, 12 aylık dönemi kapsayan analiz sonuçları hidrolojik kuraklık açısından önemlidir (Gürler 2017). SYİ analiz sonuçları aşağıda Tablo 5'te verilmiştir.

Tablo 5: Batman ili 1988-2018 yılları arası dönem için SYİ indisine göre kuraklık analizi sonuçları

\begin{tabular}{|c|c|c|c|c|c|c|c|c|c|c|}
\hline \multirow[b]{3}{*}{ YILLAR } & \multicolumn{2}{|c|}{ SYİ-YILLIK } & \multicolumn{8}{|c|}{ SYİ-MEVSIMLİK } \\
\hline & \multirow[b]{2}{*}{$\begin{array}{c}\text { INDİS } \\
\text { DEĞERİ }\end{array}$} & \multirow[b]{2}{*}{ SINIFI } & \multicolumn{2}{|c|}{$\begin{array}{c}\text { Ekim-Kasım- } \\
\text { Aralık }\end{array}$} & \multicolumn{2}{|c|}{$\begin{array}{c}\text { Ocak-Şubat- } \\
\text { Mart } \\
\end{array}$} & \multicolumn{2}{|c|}{$\begin{array}{l}\text { Nisan-Mayıs- } \\
\text { Haziran }\end{array}$} & \multicolumn{2}{|c|}{$\begin{array}{c}\text { Temmuz- } \\
\text { Ağustos-Eylül } \\
\end{array}$} \\
\hline & & & $\begin{array}{c}\text { İNDİS } \\
\text { DEĞERİ }\end{array}$ & SINIFI & $\begin{array}{c}\text { İNDİS } \\
\text { DEĞERİ }\end{array}$ & SINIFI & $\begin{array}{c}\text { INNDİS } \\
\text { DEĞERİ }\end{array}$ & SINIFI & $\begin{array}{l}\text { İNDİS } \\
\text { DEĞERİ }\end{array}$ & SINIFI \\
\hline 1988 & 2,03 & $\begin{array}{c}\text { Aşırı } \\
\text { Yağış11 }\end{array}$ & 0,62 & $\begin{array}{l}\text { Hafif } \\
\text { Yağışl1 }\end{array}$ & 1,26 & $\begin{array}{l}\text { Orta } \\
\text { Yağışl1 }\end{array}$ & 1,28 & $\begin{array}{c}\text { Orta } \\
\text { Yağışl1 }\end{array}$ & 0,16 & $\begin{array}{l}\text { Hafif } \\
\text { Yağışl1 }\end{array}$ \\
\hline 1989 & $-1,23$ & $\begin{array}{c}\text { Orta } \\
\text { Kurak }\end{array}$ & 0,98 & $\begin{array}{l}\text { Hafif } \\
\text { Yağışlı }\end{array}$ & $-0,77$ & $\begin{array}{l}\text { Hafif } \\
\text { Kurak }\end{array}$ & $-2,27$ & $\begin{array}{l}\text { Aşırı } \\
\text { Kurak }\end{array}$ & 0,00 & $\begin{array}{l}\text { Hafif } \\
\text { Kurak }\end{array}$ \\
\hline 1990 & $-1,11$ & $\begin{array}{c}\text { Orta } \\
\text { Kurak }\end{array}$ & $-0,52$ & $\begin{array}{l}\text { Hafif } \\
\text { Kurak }\end{array}$ & $-0,41$ & $\begin{array}{l}\text { Hafif } \\
\text { Kurak }\end{array}$ & 0,08 & $\begin{array}{l}\text { Hafif } \\
\text { Yağışl1 }\end{array}$ & $-0,99$ & $\begin{array}{l}\text { Hafif } \\
\text { Kurak }\end{array}$ \\
\hline 1991 & 0,84 & $\begin{array}{l}\text { Hafif } \\
\text { Yağışl1 }\end{array}$ & 1,32 & $\begin{array}{c}\text { Orta } \\
\text { Yağı̧̧1 }\end{array}$ & 0,52 & $\begin{array}{l}\text { Hafif } \\
\text { Yağışl1 }\end{array}$ & $-0,70$ & $\begin{array}{l}\text { Hafif } \\
\text { Kurak }\end{array}$ & $-0,07$ & $\begin{array}{l}\text { Hafif } \\
\text { Kurak }\end{array}$ \\
\hline 1992 & 0,39 & $\begin{array}{l}\text { Hafif } \\
\text { Yağışl1 }\end{array}$ & 0,33 & $\begin{array}{l}\text { Hafif } \\
\text { Yağışl1 }\end{array}$ & 0,13 & $\begin{array}{l}\text { Hafif } \\
\text { Yağışl1 }\end{array}$ & 0,70 & $\begin{array}{l}\text { Hafif } \\
\text { Yağışl1 }\end{array}$ & $-0,28$ & $\begin{array}{l}\text { Hafif } \\
\text { Kurak }\end{array}$ \\
\hline 1993 & 1,01 & $\begin{array}{l}\text { Orta } \\
\text { Yağışl1 }\end{array}$ & 0,02 & $\begin{array}{l}\text { Hafif } \\
\text { Yağış̧1 }\end{array}$ & 0,22 & $\begin{array}{l}\text { Hafif } \\
\text { Yağışl1 }\end{array}$ & 1,83 & $\begin{array}{l}\text { Çok } \\
\text { Yağışl1 }\end{array}$ & $-0,28$ & $\begin{array}{l}\text { Hafif } \\
\text { Kurak }\end{array}$ \\
\hline 1994 & 0,52 & $\begin{array}{l}\text { Hafif } \\
\text { Yağışlı }\end{array}$ & 1,57 & $\begin{array}{c}\text { Çok } \\
\text { Yağışl1 }\end{array}$ & 0,11 & $\begin{array}{l}\text { Hafif } \\
\text { Yağışl1 }\end{array}$ & $-1,18$ & $\begin{array}{c}\text { Orta } \\
\text { Kurak }\end{array}$ & 0,63 & $\begin{array}{l}\text { Hafif } \\
\text { Yağışl1 }\end{array}$ \\
\hline
\end{tabular}


Tablo 5'in devamı

\begin{tabular}{|c|c|c|c|c|c|c|c|c|c|c|}
\hline 1995 & $-0,07$ & $\begin{array}{l}\text { Hafif } \\
\text { Kurak }\end{array}$ & $-1,57$ & $\begin{array}{c}\text { Çok } \\
\text { Kurak }\end{array}$ & 0,67 & $\begin{array}{l}\text { Hafif } \\
\text { Yağ }{ }_{1 s ̧} l_{1}\end{array}$ & 0,31 & $\begin{array}{l}\text { Hafif } \\
\text { Yağışl1 }\end{array}$ & $-0,09$ & $\begin{array}{c}\text { Hafif } \\
\text { Kurak }\end{array}$ \\
\hline 1996 & 1,65 & $\begin{array}{l}\text { Çok } \\
\text { Yağ } 1 s ̧ l_{1}\end{array}$ & 0,40 & $\begin{array}{l}\text { Hafif } \\
\text { Yağışli }\end{array}$ & 1,57 & $\begin{array}{c}\text { Çok } \\
\text { Yağışli }\end{array}$ & $-0,50$ & $\begin{array}{l}\text { Hafif } \\
\text { Kurak }\end{array}$ & 0,53 & $\begin{array}{l}\text { Hafif } \\
\text { Yağ }{ }_{1 s ̧ 1} 1\end{array}$ \\
\hline 1997 & 0,08 & $\begin{array}{l}\text { Hafif } \\
\text { Yağışl1 }\end{array}$ & 0,32 & $\begin{array}{l}\text { Hafif } \\
\text { Yağış11 }\end{array}$ & $-0,01$ & $\begin{array}{l}\text { Hafif } \\
\text { Kurak }\end{array}$ & 0,14 & $\begin{array}{l}\text { Hafif } \\
\text { Yağ }{ }_{1 s ̧ 1}\end{array}$ & 1,36 & $\begin{array}{l}\text { Orta } \\
\text { Yağış̧1 }\end{array}$ \\
\hline 1998 & $-0,60$ & $\begin{array}{l}\text { Hafif } \\
\text { Kurak }\end{array}$ & $-1,50$ & $\begin{array}{c}\text { Çok } \\
\text { Kurak }\end{array}$ & 0,14 & $\begin{array}{l}\text { Hafif } \\
\text { Yağışli }\end{array}$ & 0,58 & $\begin{array}{l}\text { Hafif } \\
\text { Yağışl1 }\end{array}$ & $-0,30$ & $\begin{array}{c}\text { Hafif } \\
\text { Kurak }\end{array}$ \\
\hline 1999 & $-1,36$ & $\begin{array}{c}\text { Orta } \\
\text { Kurak }\end{array}$ & $-1,43$ & $\begin{array}{c}\text { Orta } \\
\text { Kurak }\end{array}$ & $-0,17$ & $\begin{array}{l}\text { Hafif } \\
\text { Kurak }\end{array}$ & $-0,02$ & $\begin{array}{l}\text { Hafif } \\
\text { Kurak }\end{array}$ & 0,21 & $\begin{array}{l}\text { Hafif } \\
\text { Yağışl1 }\end{array}$ \\
\hline 2000 & $-0,83$ & $\begin{array}{c}\text { Hafif } \\
\text { Kurak }\end{array}$ & $-0,02$ & $\begin{array}{l}\text { Hafif } \\
\text { Kurak }\end{array}$ & $-0,01$ & $\begin{array}{l}\text { Hafif } \\
\text { Kurak }\end{array}$ & $-0,90$ & $\begin{array}{l}\text { Hafif } \\
\text { Kurak }\end{array}$ & $-0,67$ & $\begin{array}{c}\text { Hafif } \\
\text { Kurak }\end{array}$ \\
\hline 2001 & 0,07 & $\begin{array}{l}\text { Hafif } \\
\text { Yağı̧̧1 }\end{array}$ & 0,56 & $\begin{array}{l}\text { Hafif } \\
\text { Yağışli }\end{array}$ & 0,05 & $\begin{array}{l}\text { Hafif } \\
\text { Yağışl1 }\end{array}$ & $-0,03$ & $\begin{array}{l}\text { Hafif } \\
\text { Kurak }\end{array}$ & $-0,43$ & $\begin{array}{c}\text { Hafif } \\
\text { Kurak }\end{array}$ \\
\hline 2002 & 0,25 & $\begin{array}{l}\text { Hafif } \\
\text { Yağışl1 }\end{array}$ & 0,54 & $\begin{array}{l}\text { Hafif } \\
\text { Yağışl1 }\end{array}$ & $-0,03$ & $\begin{array}{l}\text { Hafif } \\
\text { Kurak }\end{array}$ & 0,46 & $\begin{array}{l}\text { Hafif } \\
\text { Yağışl1 }\end{array}$ & 0,09 & $\begin{array}{c}\text { Hafif } \\
\text { Yağışl1 }\end{array}$ \\
\hline 2003 & 0,58 & $\begin{array}{l}\text { Hafif } \\
\text { Yağışl1 }\end{array}$ & $-1,67$ & $\begin{array}{c}\text { Çok } \\
\text { Kurak }\end{array}$ & 1,06 & $\begin{array}{l}\text { Orta } \\
\text { Yağ }{ }_{1 s ̧ l}\end{array}$ & 0,62 & $\begin{array}{l}\text { Hafif } \\
\text { Yağışl1 }\end{array}$ & $-0,99$ & $\begin{array}{c}\text { Hafif } \\
\text { Kurak }\end{array}$ \\
\hline 2004 & $-1,63$ & $\begin{array}{c}\text { Çok } \\
\text { Kurak }\end{array}$ & 0,31 & $\begin{array}{l}\text { Hafif } \\
\text { Yağışl1 }\end{array}$ & $-4,69$ & $\begin{array}{c}\text { Aşırı } \\
\text { Kurak }\end{array}$ & 0,66 & $\begin{array}{l}\text { Hafif } \\
\text { Yağışl1 }\end{array}$ & $-0,99$ & $\begin{array}{c}\text { Hafif } \\
\text { Kurak }\end{array}$ \\
\hline 2005 & $-0,51$ & $\begin{array}{c}\text { Hafif } \\
\text { Kurak }\end{array}$ & $-0,39$ & $\begin{array}{l}\text { Hafif } \\
\text { Kurak }\end{array}$ & 0,55 & $\begin{array}{l}\text { Hafif } \\
\text { Yağışli }\end{array}$ & $-1,54$ & $\begin{array}{c}\text { Çok } \\
\text { Kurak }\end{array}$ & $-0,09$ & $\begin{array}{c}\text { Hafif } \\
\text { Kurak }\end{array}$ \\
\hline 2006 & 1,35 & $\begin{array}{c}\text { Orta } \\
\text { Yağışl1 }\end{array}$ & 1,01 & $\begin{array}{l}\text { Orta } \\
\text { Yağışl1 }\end{array}$ & 0,79 & $\begin{array}{l}\text { Hafif } \\
\text { Yağ }{ }_{1 s ̧}{ }_{1}\end{array}$ & 0,43 & $\begin{array}{l}\text { Hafif } \\
\text { Yağışl1 }\end{array}$ & $-0,32$ & $\begin{array}{c}\text { Hafif } \\
\text { Kurak }\end{array}$ \\
\hline 2007 & $-0,72$ & $\begin{array}{c}\text { Hafif } \\
\text { Kurak }\end{array}$ & $-1,72$ & $\begin{array}{c}\text { Çok } \\
\text { Kurak }\end{array}$ & 0,08 & $\begin{array}{l}\text { Hafif } \\
\text { Yağışli }\end{array}$ & 0,66 & $\begin{array}{l}\text { Hafif } \\
\text { Yağışl1 }\end{array}$ & $-0,32$ & $\begin{array}{l}\text { Hafif } \\
\text { Kurak }\end{array}$ \\
\hline 2008 & $-1,78$ & $\begin{array}{c}\text { Çok } \\
\text { Kurak }\end{array}$ & $-0,45$ & $\begin{array}{c}\text { Hafif } \\
\text { Kurak }\end{array}$ & $-0,95$ & $\begin{array}{c}\text { Hafif } \\
\text { Kurak }\end{array}$ & $-1,39$ & $\begin{array}{c}\text { Orta } \\
\text { Kurak }\end{array}$ & 2,85 & $\begin{array}{c}\text { Aşırı } \\
\text { Yağış11 }\end{array}$ \\
\hline 2009 & $-0,44$ & $\begin{array}{c}\text { Hafif } \\
\text { Kurak }\end{array}$ & 0,39 & $\begin{array}{l}\text { Hafif } \\
\text { Yağışl1 }\end{array}$ & 0,14 & $\begin{array}{l}\text { Hafif } \\
\text { Yağışl1 }\end{array}$ & $-1,26$ & $\begin{array}{c}\text { Orta } \\
\text { Kurak }\end{array}$ & 0,19 & $\begin{array}{l}\text { Hafif } \\
\text { Yağışl1 }\end{array}$ \\
\hline 2010 & $-1,72$ & $\begin{array}{c}\text { Çok } \\
\text { Kurak }\end{array}$ & $-1,59$ & $\begin{array}{c}\text { Çok } \\
\text { Kurak }\end{array}$ & 0,06 & $\begin{array}{l}\text { Hafif } \\
\text { Yağışli }\end{array}$ & $-0,93$ & $\begin{array}{l}\text { Hafif } \\
\text { Kurak }\end{array}$ & $-0,82$ & $\begin{array}{c}\text { Hafif } \\
\text { Kurak }\end{array}$ \\
\hline 2011 & 0,73 & $\begin{array}{l}\text { Hafif } \\
\text { Yağışl1 }\end{array}$ & $-0,63$ & $\begin{array}{l}\text { Hafif } \\
\text { Kurak }\end{array}$ & $-0,52$ & $\begin{array}{l}\text { Hafif } \\
\text { Kurak }\end{array}$ & 2,55 & $\begin{array}{c}\text { Aşıırı } \\
\text { Yağ } 1 \text { lş1 }\end{array}$ & 0,91 & $\begin{array}{l}\text { Hafif } \\
\text { Yağışl1 }\end{array}$ \\
\hline 2012 & 1,42 & $\begin{array}{c}\text { Orta } \\
\text { Yağ } 1 s ̧ 11\end{array}$ & 1,64 & $\begin{array}{c}\text { Çok } \\
\text { Yağışli }\end{array}$ & 0,53 & $\begin{array}{l}\text { Hafif } \\
\text { Yağışli }\end{array}$ & 0,19 & $\begin{array}{l}\text { Hafif } \\
\text { Yağ } 1 s ̧ 11\end{array}$ & 0,55 & $\begin{array}{l}\text { Hafif } \\
\text { Yağışl1 }\end{array}$ \\
\hline 2013 & 0,36 & $\begin{array}{l}\text { Hafif } \\
\text { Yağışl1 }\end{array}$ & 0,29 & $\begin{array}{l}\text { Hafif } \\
\text { Yağ } 1 \text { lş1 }\end{array}$ & 0,33 & $\begin{array}{l}\text { Hafif } \\
\text { Yağ }{ }_{1 s ̧}{ }_{1}\end{array}$ & 0,30 & $\begin{array}{l}\text { Hafif } \\
\text { Yağışl1 }\end{array}$ & $-0,99$ & $\begin{array}{c}\text { Hafif } \\
\text { Kurak }\end{array}$ \\
\hline 2014 & 0,01 & $\begin{array}{l}\text { Hafif } \\
\text { Yağışl1 }\end{array}$ & 0,72 & $\begin{array}{l}\text { Hafif } \\
\text { Yağışl1 }\end{array}$ & $-0,29$ & $\begin{array}{c}\text { Hafif } \\
\text { Kurak }\end{array}$ & $-0,52$ & $\begin{array}{l}\text { Hafif } \\
\text { Kurak }\end{array}$ & 2,50 & $\begin{array}{c}\text { Aşırı } \\
\text { Yağışl1 }\end{array}$ \\
\hline 2015 & $-0,25$ & $\begin{array}{l}\text { Hafif } \\
\text { Kurak }\end{array}$ & $-0,34$ & $\begin{array}{c}\text { Hafif } \\
\text { Kurak }\end{array}$ & 0,47 & $\begin{array}{c}\text { Hafif } \\
\text { Yağışl1 }\end{array}$ & $-0,67$ & $\begin{array}{c}\text { Hafif } \\
\text { Kurak }\end{array}$ & 0,42 & $\begin{array}{l}\text { Hafif } \\
\text { Yağışl }\end{array}$ \\
\hline
\end{tabular}


Tablo 5'in devamı

\begin{tabular}{|c|c|c|c|c|c|c|c|c|c|c|}
\hline 2016 & 0,07 & $\begin{array}{l}\text { Hafif } \\
\text { Yağışl1 }\end{array}$ & 0,03 & $\begin{array}{l}\text { Hafif } \\
\text { Yağışl1 }\end{array}$ & 0,45 & $\begin{array}{l}\text { Hafif } \\
\text { Yağışl }\end{array}$ & $-0,28$ & $\begin{array}{c}\text { Hafif } \\
\text { Kurak }\end{array}$ & $-0,46$ & $\begin{array}{l}\text { Hafif } \\
\text { Kurak }\end{array}$ \\
\hline 2017 & $-0,33$ & $\begin{array}{c}\text { Hafif } \\
\text { Kurak }\end{array}$ & $-0,88$ & $\begin{array}{l}\text { Hafif } \\
\text { Kurak }\end{array}$ & 0,25 & $\begin{array}{l}\text { Hafif } \\
\text { Yağışlı }\end{array}$ & 0,38 & $\begin{array}{l}\text { Hafif } \\
\text { Yağışl1 }\end{array}$ & $-0,99$ & $\begin{array}{l}\text { Hafif } \\
\text { Kurak }\end{array}$ \\
\hline 2018 & 1,21 & $\begin{array}{c}\text { Orta } \\
\text { Yağ } 1 s ̧ 11\end{array}$ & 1,72 & $\begin{array}{c}\text { Çok } \\
\text { Yağışl1 }\end{array}$ & $-0,16$ & $\begin{array}{l}\text { Hafif } \\
\text { Kurak }\end{array}$ & 0,98 & $\begin{array}{l}\text { Hafif } \\
\text { Yağışl1 }\end{array}$ & $-0,46$ & $\begin{array}{l}\text { Hafif } \\
\text { Kurak }\end{array}$ \\
\hline
\end{tabular}

SYİ yıllık analiz sonuçlarına göre; Aşırı yağışlı yıl sayısı 1, Çok yağışılı yıl sayısı 1, Orta yağışlı yıl sayısı 4, Hafif yağışıı yıl sayısı 11, Çok kurak yıl sayısı 3, Orta kurak yıl sayısı 3, Hafif kurak yıl sayısı 8 olarak bulunmuştur. Bu sonuçlara göre çalışma bölgesi için yıllık analizde 17 yıl yă̆ışlı, 14 yıl kurak geçtiği belirlenmiştir. SYİ mevsimlik analizlere baktı̆̆ımızda, yanıltııı olabilecek yaz ayları dışındaki aylardan Ekim-Kasım-Aralık aylarını kapsayan 3 aylık dönemde; 18 yıl yağışlı, 13 yıl kurak olduğu, Ocak-Şubat-Mart aylarını kapsayan 3 aylık dönemde; 20 yıl yağışlı, 11 yıl kurak olduğu tespit edilmiştir. Genel itibariyle yıllık sonuçlarla uyumlu olduğu belirlenmiştir. Ancak Temmuz- Ağustos yaz aylarını kapsayan 3 aylık dönemde kurak yılların daha fazla olduğu belirlenmiştir. Bu dönemde 19 yılın kurak olduğu belirlenmiştir. Yine Haziran ayını kapsayan 3 aylık dönemde de 14 yılın kurak olduğu belirlenmiştir. Bu durumun çalışma bölgesinde yaz aylarında sıcaklıkların çok yüksek olmasından dolayı kuraklığın yüksek görünmesine neden olup, yanıltıcı sonuçlara neden olabilmektedir. Bu nedenle kuraklığın değerlendirilmesinde yıllık analizlerin yanında, bahar ve kış aylarını kapsayan mevsimlik analizlerin de dikkate alınması daha doğru sonuçlar elde etmede yararlı olmaktadır. Şekil 3 ’te SYİ indisi yıllık ve mevsimlik analiz sonuçları dairesel grafikte görselleştirilmiştir.
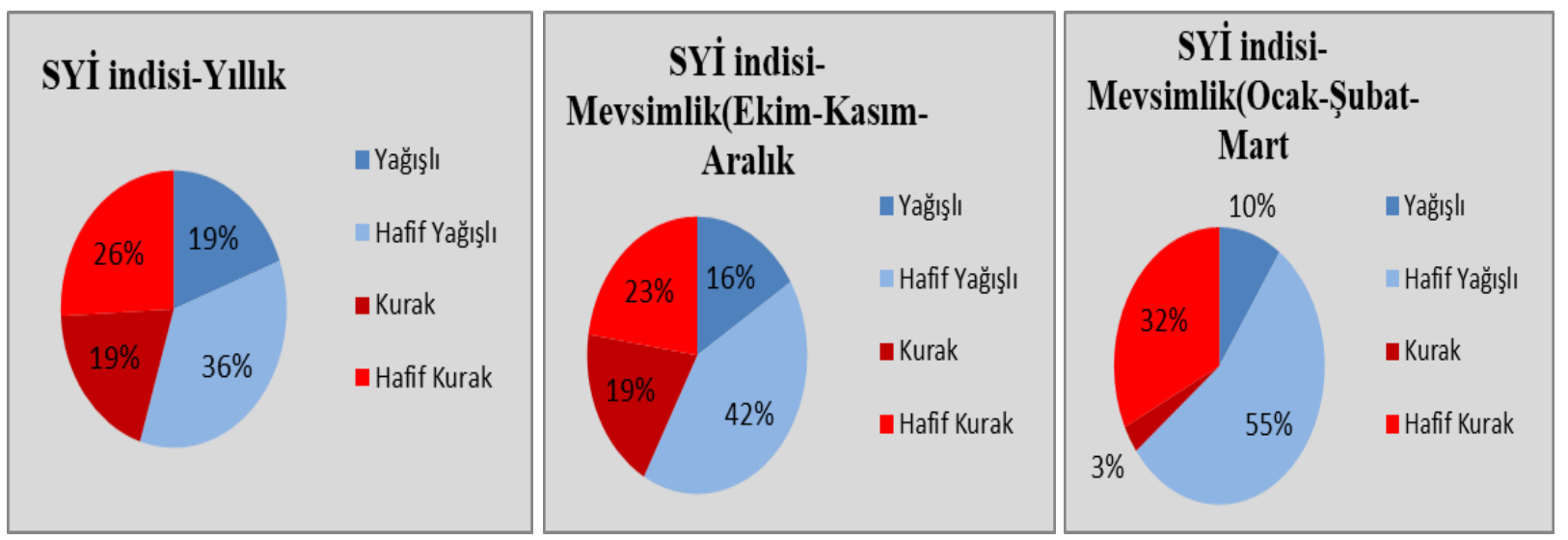

Şekil 3: SYí indisine göre Batman ili uzun yıllar yıllık ve mevsimlik kuraklık analizi sonuçlarının grafiksel gösterimi

\subsubsection{Analiz sonuçlarının SYí Yöntemi Sonuçları ve Literatür Sonuçları ile Karşılaştırılması}

Literatürde çalışma bölgesi için çok fazla çalışma bulunmamaktadır. Yapılan bir çalı̧̧mada Güneydoğu Anadolu Bölgesi’ndeki illerin "Standart Yağış İndisi (SYI)", "Erinç Kuraklık İndisi (EKİ)" ve De Martonne İndisi (DMI)" ile yağış ve sıcaklık verileri kullanılarak 1960-2015 yılları arası kuraklık analizleri yapılmıştır. DMİ yöntemi analiz sonuçlarının haritalanmış hali Şekil 4'te verilmiştir. Bölgedeki iller içinde Batman ili için SYİ yöntemine göre; 12-24 aylık periyotta şiddetli ve çok şiddetli kuraklığın görüldüğü, EKİ yöntemine göre; \%62,26 ile kurak, \%30,19 ile yarı kurak olduğu, DMİ yöntemine göre ise Batman merkez istasyonu için 7,75 indis değeriyle yarı kurak olduğu tespit edilmiştir (Oruç 2017). DMİ sonuçlarına göre Şekil 4'teki haritada Batman ili hafif kurak olarak gösterilmiştir. Ancak, Batman ilinin ilçesi olan Sason istasyonu sonuçları da dikkate alındığında hafif kurak çıkmaktadır. Batman İli merkez istasyonu sonuçlarına göre Batman yarı kurak çıkmaktadır. Bu çalışmada Batman merkez istasyonu sonuçlarına göre analizler yapıldığı için literatürdeki DMİ indisi sonucu doğru karşılaş̧ırma yapılabilmesi için yarı kurak kabul edilmiştir. 


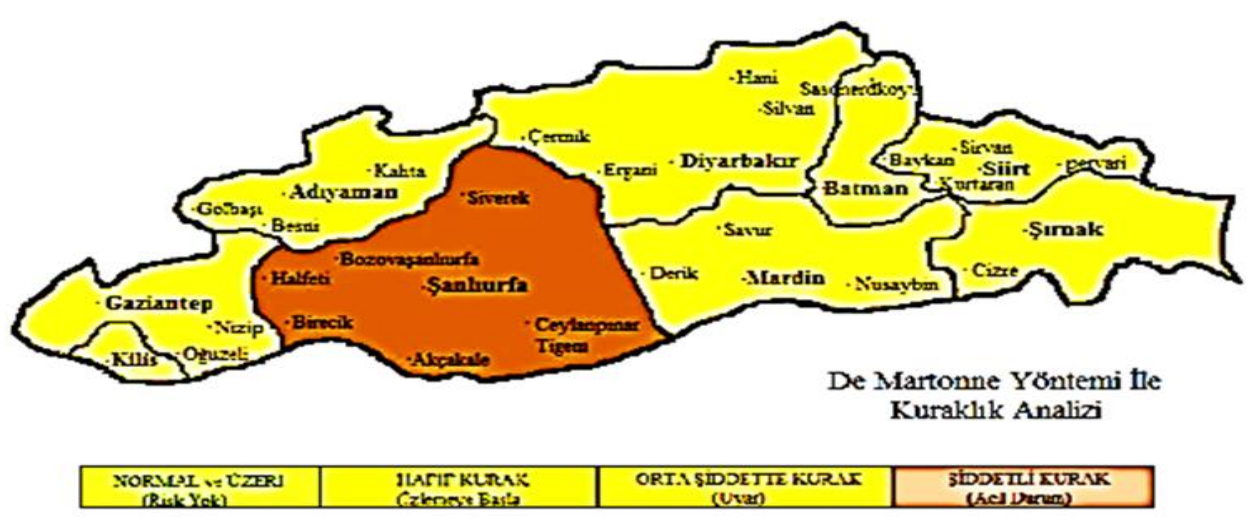

Şekil 4: De Martonne indeksine göre Güneydoğu Anadolu Bölgesi’ndeki illerin kuraklık analiz sonuçları (Oruç 2017)

Literatürdeki bu sonuçlar ile bu çalışmanın sonuçları karşılaştırıldığında genel itibariyle uyumlu olduğu görülmüştür. Şöyle ki; literatürde Batman ili için SYİ yöntemine göre şiddetli ve çok şiddetli kurak, EKİ yöntemine göre büyük bir yüzdeyle kurak ve DMİ yöntemine göre yarı kurak olduğu tespit edilmiştir. Bu çalışmada da NYİ yöntemi dışında diğer 3 yöntemin literatürdeki çalışmayla büyük oranda benzerlik gösterdiği görülmüştür. Çünkü bu çalışmada; BGİ yöntemine göre Batman ili çok kurak, DMGİ yöntemine göre yarı kurak ve MFİ yöntemine göre büyük bir oranla az yağışlı(kurak veya yarı kurak) çıkmıştır. Sadece NYİ yöntemi sonuçları hem literatürdeki diğer yöntemler hem de bu çalışmadaki yöntemlerle uyumlu çıkmamıştır. Bu çalışmada yapılan SYİ yıllık analizine göre; hafif yağışlı yıl sayısı 11, kurak yıl sayısı 14 olarak belirlenmiştir. Yaz ayları dışındaki Ekim-Kasım-Aralık mevsimlik(3 aylık) dönemde ise; 11 yıl hafif yağışılı,13 yıl kurak olduğu belirlenmiştir. Yine yaz ayları dışındaki Ocak-Şubat-Mart mevsimlik(3 aylık) dönemde ise; 17 yıl hafif yağışlı, 13 yıl kurak olduğu belirlenmiştir. Bu çalışmada yapılan SYİ yöntemi sonuçlarına göre, diğer yöntem sonuçları ve literatürdeki çalışma sonuçları gibi kurak yıllar daha fazla çıkmasa da genel itibariyle uyumlu oldukları, bu çalışmada yapılan SYİ yöntemi sonuçlarına göre hafif yağışlı yılların fazla çıktığı görülmüştür. NYİ dışındaki 6 farklı yöntemin sonuçları büyük ölçüde benzerdir. Güneydoğu Anadolu Bölgesinde bulunan Batman ilinin sıcaklık ortalamalarının yüksek olduğu ve yazın buharlaşmanın çok fazla olduğu(Gümüş vd. 2018) düşünüldüğünde birbiriyle uyumlu olan bu 6 yöntemin sonuçlarının doğru olduğu düşünülmektedir. Ayrıca, Batman ili ölçeğinde yapılan kuraklık analizlerinde NYİ indisi yönteminin iyi sonuçlar vermediği de söylenebilir. NYİ analiz sonuçlarının diğer yöntemlerle uyumsuz olmasının nedenleri de araştırmacılar tarafından daha kapsamlı araştırılabilir.

\subsection{Analiz Sonuçlarının Haritalanması}

Yapılan analiz sonuçlarını görselleştirmek için kontur haritaları çıkarılarak haritalanmıştır. Haritalarda kuraklık şiddeti kırmızı renkten mavi renge doğru azalmaktadır. Haritalarda eş yükselti eğrilerine benzer eğriler; kullanılan kuraklık indisi değerlerinin eşit olduğu noktalar birleştirilerek oluşturulmuştur. Yani kontur haritasındaki her çizgi üzerindeki kuraklık indisi değeri eşittir. Bu sayede kontur haritalarıyla analiz sonuçlarının görselleştirilmesinin yanında indis değerlerinin eşit olduğu yerlerden geçen eğrileri de görebilmekteyiz.

Sonuçların haritalanmasında Surfer haritalama programı kullanılarak, 3 değişkenli fakat 2 boyutlu kontur haritaları elde edilmiştir. Surfer programıyla kontur haritası elde etmek için 1 bağımlı değişken ve 2 bağımsız değişken olması gerekir. Bağımsız değişkenler, X ve Y eksenlerinde gösterilir, bağımlı değişken değerleri ise bağımsız değişkenlere bağlı olarak eğriler şeklinde çizilir (Toprak 2004; Toprak ve Savc1 2005). Kuraklık indisleri formülleri incelendiğinde NYİ ve DMGİ formüllerinde ikiden fazla bağımsız değişken bulunmaktadır. Bu nedenle NYİ ve DMGİ değerlerinin SURFER ile haritalanması çok mantıklı sonuçlar vermeyeceği için yapılmamıştır. Bu nedenle aşağıda sadece MFİ ve BGİ analiz sonuçları kontur haritaları elde edilmiştir. İndis değeri kurak duruma karşılık geliyorsa kırmızı renkte renklendirilmiştir.

Çıkarılan kontur haritalarının yanında ölçek bulunmaktadır. Bu ölçekler her yöntemin analiz sonuçları indis değerlerine göre oluşturulmuştur. Ölçek, yapılan analiz sonuçlarına göre ilgili kuraklık indisi değerlerini en küçükten en büyüğüne kadar kapsayacak şekilde oluşturulmuştur. Bu yüzden her yöntem için ölçek değişkenlik göstermektedir. Örneğin Modifiye Fournier yönteminde ölçek 155'e kadar, Bagnauls-Gaussen yönteminde ölçek 300'e kadar oluşturulmuştur.

\subsubsection{Modifiye Fournier İndisi (MFi) Analiz Sonuçları Kontur Haritası}

MFİ yöntemi formülü incelendiğinde $P i$ ve $P$ değerleri bağımsız değişken, MFİ değeri de bağımlı değişkendir. Yani kontur haritası oluşturulabilmesi için gerekli olan 3 sütun veri vardır. Aşağıda Şekil 5.'te 31 yıllık verilere göre Ocak ayı ve Haziran ayı kontur haritaları elde edilmiştir. MFİ yönteminde yıllık bazda haritalama yapıldığında; Surfer haritalama programında kontur haritası yapmak için gerekli olan 2 bağımsız değişken 1 bağımlı değişken kuralına uyulamayacağı için aylık bazda haritalama yapılmıştır. 
Bu nedenle, 31 yıl için, kış ayı olan Ocak ve yaz ayı olan Haziran ayı için haritalama yapılmıştır. MFİ kontür haritasında $\mathrm{X}$ ekseni $P i$ değerlerini, Y ekseni de $P$ değerlerini göstermektedir. Haritadaki eğriler de MFİ indis değerlerini göstermektedir.

Şekil 2.'deki MFİ ve BGİ dairesel grafiklere bakıldığında BGİ dairesel grafiğinde kırmızı alanlar, yani kurak alanlar MFİ dairesel grafiğine göre fazladır. Şekil 5 ve Şekil 6.'daki MFİ ve BGİ kontur haritaları da karşılaştırıldığında BGİ kontur haritasında kırmızı alanlar MFİ kontur haritasına göre fazladır. Yani Şekil 2.'deki MFİ ve BGİ dairesel grafikleri ile Şekil 5. ve Şekil 6.'daki MFİ ve BGİ kontur haritalarıyla uyumlu olduğu görülmektedir. Kontur haritalarında kırmızı renkler kuraklığın olduğu zaman dilimlerini göstermektedir. Kırmızı renk dağılımına MFİ ve BGİ kontur haritalarında bakıldığında BGİ kontur haritasında kırmızı renk dağılımının yoğun olduğu görülür. Yani, BGİ kontur haritası bu çalışmada kullanılan kurak yılların daha fazla çıktığı 3 yöntem ile Batman ili için literatürde bulunan ve kurak yılların daha fazla çıktığı 3 yöntemle daha uyumlu olduğu görülür.

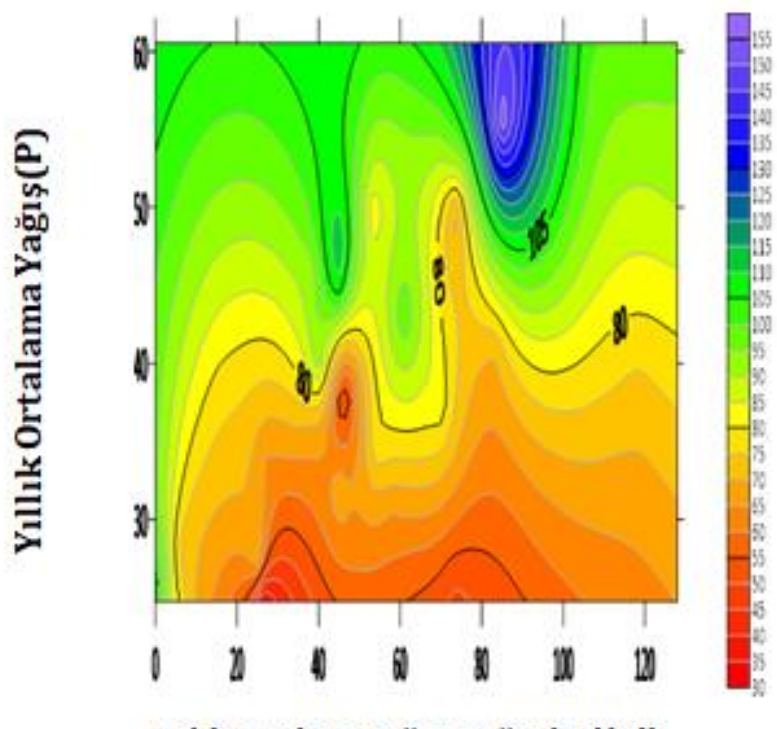

Aylık Toplam Yağış Değerleri(Pi)

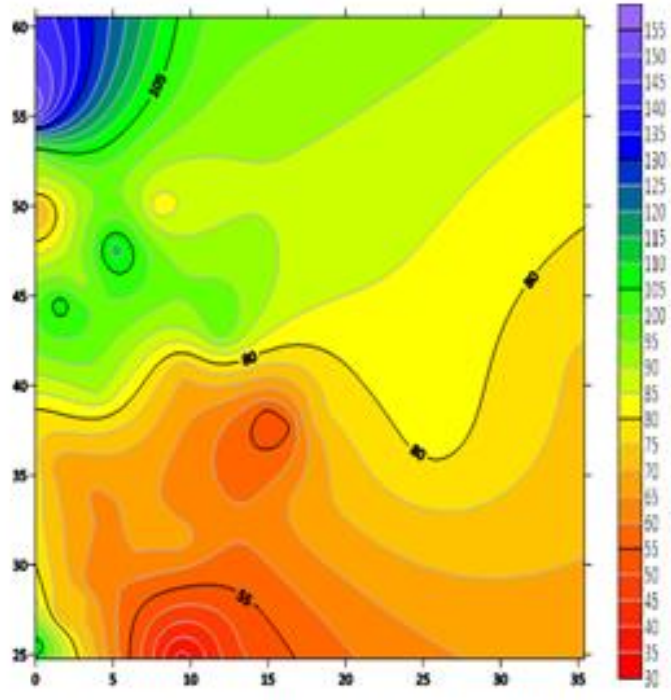

Aylık Toplam Yağış Değerleri(Pi)

Şekil.5: Modifiye Fournier Indisi 1988-2018 yılları arası Ocak ayı(soldaki) ve Haziran ayı(sağdaki) kuraklık kontur haritası

\subsubsection{Bagnauls Gaussen İndisi (BGi) Analiz Sonuçları Kontur Haritası}

BGİ formülündeki aylık ortalama sıcaklık olan $t i$ değerleri ve aylık toplam yağış değerleri olan $P i$ değerleri bağımsız değişkenlerdir. Şekil 6.' daki kontur haritasında X ve Y eksenleri $t i$ ve $P i$ değerlerinden oluşmaktadır. Haritadaki eğriler ve yanında verilen ölçekteki değerler bağımlı değişken olan DMGİ indis değerlerini ifade etmektedir.

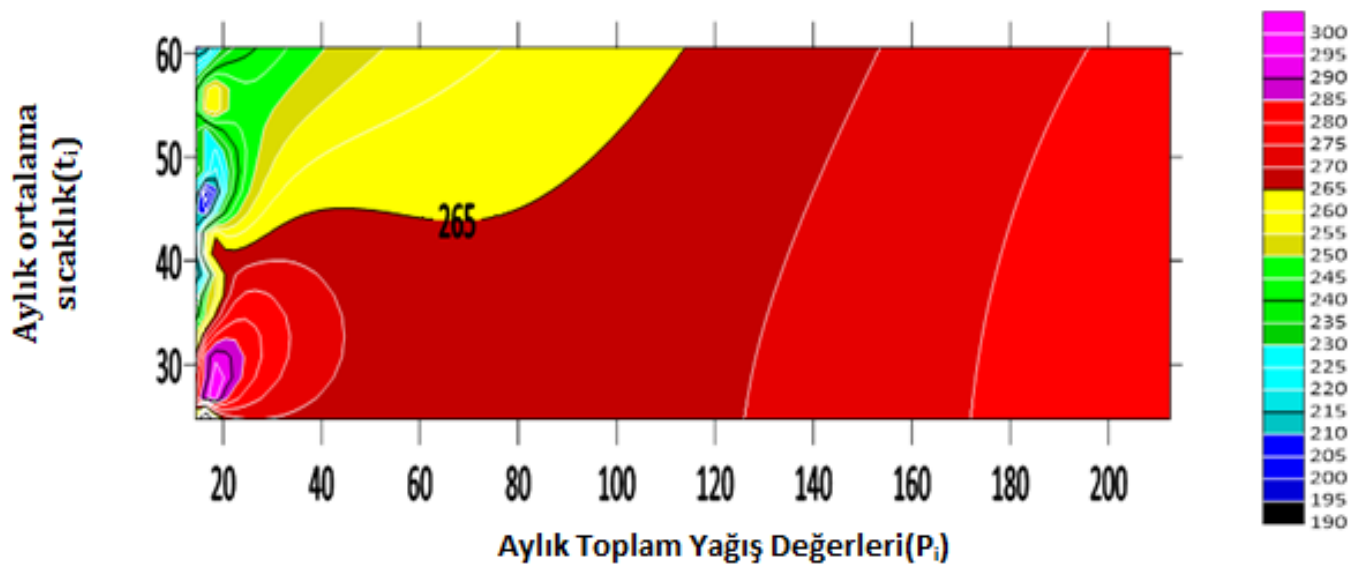

Şekil 6: Bagnauls Gaussen Indisi 1988-2018 yılları arası kuraklık kontur haritası 


\section{Sonuçlar ve Öneriler}

Bu çalı̧̧mada kuraklıkla mücadele eden Güneydoğu Anadolu Bölgesi’nde bulunan Batman ilinin 5 farklı kuraklık indisiyle 1988-2018 yılları arası uzun dönem veriler kullanılarak kuraklık analizleri yapılmıştır. Bu yöntemler; sadece yağış verilerini dikkate alan Normalin Yüzdesi İndisi (NYİ) ve Modifiye Fournier İndisi (MFi) ile yağış verilerinin yanında sıcaklık verilerini de dikkate alan De Martonne Gotmann İndisi (DMGİ) ve Bagnauls Gaussen İndisi (BGI) ile karşılaştırma için kullanılan ve sadece yağış verilerini dikkate alan Standartlaştırılmış Yağış İndisi (SYİ) yıllık ve mevsimlik analizleridir.

Elde edilen analiz sonuçlarına göre; yağış verileriyle sınıflandırma yapan NYİ yöntemine göre; 23 yılın normal olduğu, 1 yılın hafif kurak, 5 yılın orta kurak, 2 yılın şiddetli kurak olduğu, MFİ yöntemine göre; 4 yılın çok az yağışll, 18 yılın az yağışlı, 8 yılın orta yağış̧ı ve 1 yılın yüksek yağışlı olduğu, DMGİ yöntemine göre; 10 yılın yarı kurak-nemli arası, 21 yılın yarı kurak olduğu ve BGİ yöntemine göre ise tüm yılların çok kurak olduğu tespit edilmiştir. SYİ yöntemi yıllık analiz sonuçlarına göre; Aşırı yağışlı yıl sayısı 1, Çok yağışılı yıl sayısı 1, Orta yağışı yıl sayısı 4, Hafif yağışılı yıl sayısı 11, Çok kurak yıl sayısı 3, Orta kurak yıl sayısı 3, Hafif kurak yıl sayısı 8 olarak bulunmuştur. SYİ mevsimlik analizlere baktığımızda, yanıltıcı olabilecek yaz ayları dışındaki aylardan Ekim-Kasım-Aralık aylarını kapsayan 3 aylık dönemde; 18 yıl yağışlı, 13 yıl kurak olduğu, Ocak-Şubat-Mart aylarını kapsayan 3 aylık dönemde; 20 yıl yăğışlı, 11 yıl kurak olduğu tespit edilmiştir.

$\mathrm{Bu}$ sonuçlar Batman ili için literatürde yapılan uzun dönem kuraklık analiz sonuçlarıyla karş̧laştırıldığında NYI yöntemi dışındaki diğer 4 yöntemin literatür çalışmalarıyla uyumlu olduğu belirlenmiştir. SYİ yönteminde kurak yıllar daha az olsa da NYİ dışındaki diğer 3 yöntemle yakın sonuçlar elde edilmiştir. Hafif yağışlı yıl sayısı daha fazla çıkmışıır. Batman ili ölçeğinde yapılacak uzun dönem kuraklık analizlerinde Modifiye Fournier İndisi (MFİ), Bagnauls Gaussen İndisi (BGI), De Martonne-Gotmann İndisi (DMGİ) ve Standartlaştırılmış Yağış İndisi (SYI) yöntemlerinin kullanılabileceği görülmüştür. Ayrıca, Batman ili için ilk kez yapılan kuraklık analizi sonuçlarından Modifiye Fournier İndisi(MFI) analiz sonuçlarının ve Bagnauls Gaussen İndisi(BGI) analiz sonuçlarının SURFER haritalama programıyla kontur haritaları çıkarılmıştır. BGİ kontur haritasında kırmızı renk dağılımın fazla olması nedeniyle analiz sonuçlarını daha iyi yansıttığı görülmüştür.

Bu çalışmada NYİ ve SYİ yöntemi dışında diğer 3 yöntemin analiz sonuçlarına göre Batman ilinde kurak yılların daha fazla olduğu görülmüş̧ür. SPİ yönteminde de neredeyse yılların yarısına yakını kurak çıkmış ve yağışlı yıllarda da hafif yağışlı yıl sayısı fazla çıkmıştır. Bunun nedenleri arasında Batman ilinin konum itibariyle kurak iklime sahip Güneydoğu Anadolu Bölgesinde olması nedeni ile yazları çok sıcak geçmesi, yağış miktarlarının özellikle yaz aylarında düşmesi ve buharlaşmanın çok fazla olması sayılabilir. Bu durum göz önünde bulundurularak literatürde en fazla kullanılan SYİ yöntemi ile mevsimlik analizler de yapılıp daha gerçekçi kuraklık tespitleri yapılmıştır. Çünkü yaz ayları yüksek sıcaklıktan dolayı kuraklık analizinde yanıltıcı sonuçlar verebilmektedir. Batman ilinde ağaçlandırmanın yetersiz olması buharlaşma kayıplarını artırmakta, su tasarrufu sağlayan sulama sistemlerinin yeterli düzeyde olmaması da kuraklığın etkilerini şiddetlendirmektedir. Batman ili için bu olumsuzluklar giderilerek ve hatta su ayak izi analizleri yapılıp, su tüketimi az tarım ürünlerinin belirlenip, bu doğrultuda planlamaların hayata geçirilmesi önerilmektedir. Bölgede çok ciddi düzeyde olan buharlaşma kayıplarının önüne geçilmesi açısından yeraltı barajlarının yapılması da kuraklıkla mücadeleye katkı sağlayacaktır.

Ayrıca, Batman ili ölçeğinde NYİ yönteminin diğer yöntemlerden çok farklı sonuçlar vermesinin nedenleri de araştırmacılar tarafından kapsamlı olarak araştırılmasının yararlı olacağı düşünülmektedir.

\section{Kaynaklar}

Akar Ö., Oğuz İ., Yürekli K., (2015), İki kara havzasının kurak ve ıslak dönemlerinin bazı kuraklık indisleri yardımıyla karşılaştırılması, Gaziosmanpaşa Üniversitesi Ziraat Fakültesi Dergisi, 32(2), 7-13.

Arslan O., Bilgil A., Veske O., (2016), Standart yağı̧̧ indisi yöntemi ile Kızılırmak havzası'nın meteorolojik kuraklık analizi, Niğde Üniversitesi Mühendislik Bilimleri Dergisi, 5(2), 188-194.

Aktaş S., Kalyoncu Ü.Y., Kılı̧ N.C.A., (2018), Eğirdir göl havzasının De Martonne yöntemi ile kuraklık analizi, Mühendislik Bilimleri ve Tasarım Dergisi, 6(2), 229-238.

Batan M., (2014), Küresel iklim değişikliği ve beklenen sonuçları, Doktora Tezi, Dicle Üniversitesi, Fen Bilimleri Enstitüsü, Diyarbakır.

Batan M., Toprak Z.F., (2015), Küresel iklim değișikliğinin olumlu etkileri ve bu etkilerin iklim değişikliğine uyum kapsamında değerlendirilmesi, Dicle Üniversitesi Mühendislik Dergisi, 6(2), 93-102.

Blenkinsop S., Fowler H. J., (2007), Changes in drought frequency, severity and duration for the British Isles projected by the prudence regional climate models, Journal of Hydrology, 342(1-2), 50-71.

Bryant E.A., (1993), Natural hazards, Cambridge University Press, Cambridge, England, 294ss.

Choi M., Jacobs J. M., Anderson M. C., Bosch D. D., (2013), Evaluation of drought indices via remotely sensed data with hydrological variables, Journal of Hydrology, 476, 265-273.

Dabanlı İ., (2017), Türkiye'de iklim değişikliğinin yă̆ış-sıcaklı̆̆a etkisi ve kuraklık analizi, Doktora Tezi, İstanbul Teknik Üniversitesi, Fen Bilimleri Enstitüsü, İstanbul.

Dai A., (2011), Drought under global warming: A review. Wiley Interdisciplinary Reviews. Climate Change, 2(1), 45-65.

Dikici M., (2019), Asi havzası'nda (Türkiye) kuraklık analizi, Doğal Afetler ve Çevre Dergisi, 5(1), 22-40. 
Dikici M., Aksel M., (2019), Comparison of Spi, Spei and Srı drought indices for Seyhan basin, International Journal of Electronics, Mechanical and Mechatronics Engineering, 9(4), 1751-1762.

Doğan S., Berktay A. Singh V.P., (2012), Comparison of multi-monthly rainfall-based drought severity indices, with application to semi-arid Konya closed basin, Turkey, Journal of Hydrology, 470, 255-268.

Edossa D.C., Babel M.S., Gupta A.D., (2010), Drought analysis in the Awash river basin, Ethiopia, Water Resources Management, 24, 1441-1460.

Efe B., Özgür E., (2014), Standart yağış indeksi (Spi) ve Normalin yüzdesi metodu (Pni) ile Konya ve çevresinin kuraklık analizi, II. Uluslararası Katılımlı Kuraklık ve Çölleşme Sempozyumu, Bildiriler Kitabı, 16-18 Eylül, Konya, Türkiye.

Faiz M.A., Liu D., Fu Q., Naz F., Hristova N., Tianxiao L., Niaz Y., Khan A., (2020) Assessment of dryness conditions according to transitional ecosystem patterns in an extremely cold region of China, Journal of Cleaner Production, 255(3), 1-11.

Guardiola-Claramonte M., Troch P. A., Breshears D. D., Huxman T. E., Switanek M. B., Durcik M., Cobb N. S., (2011), Decreased streamflow in semi-arid basins following drought-induced tree die-off: A counter-intuitive and indirect climate impact on hydrology, Journal of Hydrology, 406(3-4), 225-233.

Gümüş V., Başak A., Oruç N., (2016), Standartlaştırılmış yağış indeksi (SYİ) yöntemi ile Şanlıurfa istasyonunun kuraklık analizi, Harran University Journal of Engineering, 1(1), 36-44.

Gümüş V., Yenigün K., Toprak Z.F., Baçi N.O., (2018), Şanlıurfa ve Diyarbakır istasyonlarında slcaklık tabanlı buharlaşma tahmininde Ysa, Anfis ve Gep yöntemlerinin karşılaştırılması, Dicle Üniversitesi Mühendislik Dergisi, 9(1), 553-562.

Gürler Ç., (2017), Beyşehir ve Konya-Çumra-Karapınar alt havzalarında standartlaştırılmış indis yaklaşımı ile hidrolojik kuraklık değerlendirmesi, Uzmanlık Tezi, Su Yönetimi Genel Müdürlüğü, T.C. Orman ve Su İşleri Bakanlığı, Ankara.

Hamidi N., (2013a), Diyarbakır ili için Thornthwaite ve Standart yağış indisi yöntemleri ile kuraklı̆̆ın belirlenmesi, III. Türkiye İklim Değişikliği Kongresi, Bildiriler Kitabı, 3-5 Haziran, İstanbul, Türkiye.

Hamidi N., (2013b), Kuraklık indisinin Smrgt yöntemi ile modellenmesi, III. Türkiye İklim Değişikliği Kongresi, Bildiriler Kitabı, 3-5 Haziran, İstanbul, Türkiye.

Hamidi N., (2018), Temperature-rainfall and drought analysis for Diyarbakir city, Turkey, International Journal of Scientific and Technological Research, 4(10),572-582.

Hinıs M.A., (2013), Hydrometeorological drought analysis in Aksaray by aggregate drought index, Journal of the Faculty of Engineering and Architecture of Gazi University, 28(4), 711-721.

Hisdal H., Tallaksen L. M., (2003), Estimation of regional meteorological and hydrological drought characteristics, Journal of Hydrology, 281, 230-247.

Jain V.K., Pandey R.P., Jain M.K., Byun H., (2020), Comparison of drought indices for appraisal of drought characteristics in the Ken river basin, Weather and Climate Extremes, 8, 1-11.

Kao S. C., Govindaraju R. S., (2010), A copula-based joint deficit index for droughts, Journal of Hydrology, 380(1-2), 121-134.

Mishra A. K., Singh V. P., (2010), A review of drought concepts, Journal of Hydrology, 391(1-2), 202-216.

Oruç N., (2017), Güneydoğu Anadolu Bölgesi'nin kuraklık analizi, Yüksek Lisans Tezi, Pamukkale Üniversitesi, Fen Bilimleri Enstitüsü, Denizli.

Partal T., Yavuz E., (2020), Batı Karadeniz Bölgesi'nde kuraklık indisleri üzerine trend analizi uygulanması, Doğal Afetler ve Çevre Dergisi, 6(2), 345-353.

Salehnia N., Alizadeh A., Sanaeinejad H., Bannayan M., Zarrin A., Hoogenboom G., (2017), Estimation of meteorological drought indices based on Agmerra precipitation data and station-observed precipitation data, Journal of Arid Land, 9(6),797-809.

Şen Z., (1978), Autorun analysis of hydrological time series, Journal of Hydrology, 36, 75-85.

Şen Z., (1998), Probabilistic formulation of spatio-temporal drought pattern, Theoretical and Applied Climatology, 61(3-4), 197-206.

Şimşek O., Çakmak B., (2020), SPİ ve PNI yöntemleriyle tarım yılı kuraklık analizi, https://www.mgm.gov.tr/FILES/genel/makale/ SPIvePNIkuraklik.pdf [Erişim 7 Temmuz 2020].

Tadic L., Dadic T., Bosak M., (2015), Comparison of different drought assessment methods in continental Croatia, Gradevinar, 67(1), $11-22$.

Taş M., Kilit M., (2015), Farklı yaklaşımlarla Afyonkarahisar ilinin kuraklık analizi, 4.Uluslararası Katılımlı Toprak ve Su Kaynakları Kongresi, Bildiriler Kitabı, 1-4 Eylül, Kahramanmaraş, Türkiye.

Tigkas D., Vangelis H., Tsakiris G., (2015), Drinc: A software for drought analysis based on drought indices, Earth Science Informatics, 8(3), 697-709.

Toprak Z.F., (2004), Akarsularda boyuna dispersiyon katsayısının bulanık mantık yöntemi ile belirlenmesi, Doktora Tezi, İstanbul Teknik Üniversitesi, Fen Bilimleri Enstitüsü, İstanbul.

Toprak Z.F., Savc1 M.E., (2005), Interpreting of fuzzy dispersion model by contour map method, ITU Journal, Engineering Serial, 4(3), $39-52$.

URL-1, (2020), Batman İl Kültür ve Turizm Müdürlüğü, https://batman.ktb.gov.tr/TR-56576/cografya.html, [Erişim 11 Temmuz 2020]

URL-2, (2020), https://www.lafsozluk.com/2012/01/batman-ilinin-turkiye-haritasindaki-yeri.html, [Erişim 5 Temmuz 2020].

URL-3, (2020), Meteoroloji Genel Müdürlüğü, https://www.mgm.gov.tr/veridegerlendirme/kuraklikanalizi.aspx?d=yontemsinif, [Erişiom 15 Temmuz 2020].

Xu K., Yang D., Yang H., Li Z., Qin Y., Shen Y., (2015), Spatio-temporal variation of drought in China during 1961-2012: A climatic perspective, Journal of Hydrology, 526, 253-264.

Yenigun K., Ibrahim W. A., (2019), Investigation of drought in the Northern Iraq region, Meteorological Applications, 26(3), 490499.

Y1lmaz M., (2017), Drought analysis of Konya closed basin with the use of tmpa satellite-based precipitation data, Journal of the Faculty of Engineering and Architecture of Gazi University, 32(2), 541-549. 